\title{
Moc sterowania matematycznego
}

\section{Wprowadzenie}

Matematyka szkolna kojarzy się z rozwiązywaniem „słupków"; ewentualnie $-\mathrm{w}$ bardziej elitarnych warunkach $-\mathrm{z}$ udowadnianiem twierdzeń, zwykle już przez kogoś dawno temu udowodnionych. Jednym słowem - konieczna społecznie nuda, połączona czasem ze strachem, że nie zda się egzaminu, matury albo nie przejdzie „z klasy do klasy”. Innymi słowy - żadnej „mocy” w matematyce jako takiej nie ma. Podobne skojarzenia to albo porażka systemu oświaty (nauki), albo - co gorsza - jego poważna choroba, którą - w przeciwieństwie do jednorazowego niepowodzenia - leczyć będą długo kolejne pokolenia, o ile w ogóle uświadomią sobie ten niezdrowy stan, co już nie raz przydarzyło się w ludzkiej historii. W każdym przypadku takie i temu podobne marginalizowanie matematyki to zwiastun nadchodzącej epoki ciemnej, w której społeczeństwo jest kierowane głównie do konsumpcji i produkcji, do niemyślenia istotnego, co prowadzi do używania argumentów siły, a nie do mocy racji. Odgórne sterowanie, mające na celu zminimalizowanie kultury matematycznej lub sprowadzanie jej do przysłowiowych pustych ,słupków”, jest społecznym sterowaniem autodestrukcyjnym. Usuwanie matematycznej racjonalności daje jedynie chwilowe złudzenie, że światem steruje jakiś (u)rząd, a nie 
zaś dostępna poznawczo wszystkim, transcendująca ludzkie instytucje, niezależna od ras i poglądów moc sterowania matematycznego. Różne są jego poziomy: inną moc (łac. virtus) mają bity, inną liczby i punkty, inną równania różniczkowe itd. Nauczanie matematyki powinno to uczniom przybliżać. Szkoła traci swój etos, gdy biorą się za nią opłacani urzędnicy, a nie wychowawcy wprowadzający ucznia w świat prawdy i wartości. Dlatego trzeba cenić tych nauczycieli, którzy otwierają studentów na świat wolny od przemijających ideologii, przynajmniej w ramach swojej specjalności. Czy można znależć dzisiaj takich mistrzów?

Richard P. Feynman (1918-1988) był pod wieloma względami dziwnym, choć genialnym, a niekiedy nawet cynicznym człowiekiem. Jednak w swoich wykładach - na ile to było możliwe - unikał wspomnianych wyżej skrajności i ukazywał przynajmniej to, jak potężna jest matematyczna moc sterująca Kosmosem ${ }^{1}$. Co ciekawe, na amerykańskim fizyku, nobliście (1965), być może na skutek zaniedbań środowiskowych, ciążyła niechęć do filozofii, zupełnie analogiczna jak u innych do ,słupkowej” matematyki. Choć oficjalnie nie cenił sobie myślenia filozoficznego, to jednak w Feynmanowskim podejściu do nauki ukryta była implicite filozofia ,anonimowa", przejawiająca się bardziej w twórczości, a mniej w deklaracjach. Jego prace ujawniają głęboką znajomość, więcej - jakby wewnętrzne doświadczenie fizyki, co przejawia się zwłaszcza w tych treściach, w których słupki liczb przestają być puste, gdyż za ich wartościami kryją się wyniki doświadczeń, obserwacji - świadectwo prawdziwej rzeczywistości, którą kontemplować może jedynie prawdziwy uczony lub filozof. Feynman zawsze reagował krytycznie i ostro wobec tego, co można by określić modnym dziś terminem „rzeczywistości wirtualnej” - spreparowanej, nierealnej drogi postępowania czy myślenia, bez liczenia się z realnym, fizycznym światem - pokusy, która tak często sprowadza na manowce wielu filozofów, także tych, którzy tylko deklarują, że zajmują się rze-

${ }^{1}$ Por. R.P. Feynman, R.B. Leighton, M. Sands, Feynmana wykłady z fizyki, t. I, cz. 1, Warszawa: PWN, 1968. 
czywistością. Choćby z tego względu amerykański fizyk, nie będąc ,zawodowcem”, ma na filozofię ważny wpływ, gdyż chciał mówić o tym, co jest ${ }^{2}$.

\section{Tajemnica słupka liczb}

Feynman swą niejawną filozofię fizyki niejako przemycał w swoich wykładach, które były misterną i przemyślaną kompozycją. Jej najprostsze elementy, takie jak liczby, punkty, wykresy itd. odsłaniały tu swe fizyczne i racjonalne znaczenie, zakryte w chaotycznym doświadczeniu potocznym. Przykładem ważnego, bardzo prostego „słupka” liczb jest m.in. Tabela $2.1^{3}$, w której zawarta jest charakterystyka widma promieniowania elektromagnetycznego. Ustawione w kolumnie liczby nie są przypadkowe czy sterowane, jak sondaże przedwyborcze, mające jedynie sprawiać wrażenie matematycznych, a więc naukowych, rzetelnych. Liczby te, choć jeszcze może nie bardzo wyraźnie, przedstawiają jednak ilościowe, matematyczne sterowanie rzeczywistością nie tylko tą, lokalną, w wymiarze sali lekcyjnej czy państwa, ale całego Kosmosu. Jeden wiersz tej tabelki, np. ,światło widzialne”, czyli fala elektromagnetyczna o częstotliwości $5 \cdot 10^{14}-10^{15} \mathrm{~Hz}$, nie jest wrażliwy na żadną, nawet wyliczoną, propagandę złudzeń.

Słupek liczb opisujących widmo elektromagnetyczne jest ,śladem" porządku wyższego rzędu, dla którego liczby stanowią obiektywny nośnik prawdy, z którą się nie polemizuje, ale rozumnie uznaje. Gdyby jakiś konstruktor zaprojektował lampę zgodnie z wszystkimi kanonami technologii, ignorując jedynie Tabelę 2.1, mogłoby się okazać, że urządzenie funkcjonuje w obszarze promieni

2 Feynman, stroniąc od głębszej refleksji całościowej, pozostawał z dala od „oficjalnej” filozofii. Może było to także związane z jego kontrowersyjnym zachowaniem etycznym? Niektórzy fizycy uważali jednak Feynmana za ,jjednego z największych filozofów", jeśli idzie, oczywiście, o przyrodę. Czytelnik zainteresowany postacią i życiem Feynmana może sięgnąć do: J. Gleick, Geniusz. Życie i nauka Richarda Feynmana, [przeł.] P. Amsterdamski, [red.] A. Kowalska, Poznań: Zysk i S-ka Wydawnictwo, 1999; cyt. - tamże, s. 438.

${ }^{3}$ Por. R.P. Feynman, R.B. Leighton, M. Sands, dz. cyt., s. 40. 
$\gamma\left(10^{27} \mathrm{~Hz}\right)$; taka lampa nikogo by nie „oświeciła”, a firmie, przedwcześnie propagujacej „,nowoczesne oświetlenie $\gamma$ ”, taki „wynalazek” przyniósłby jedynie bankructwo.

Z drugiej strony, wydawać by się mogło, że Tabela 2.1 jest zbyt sztywną tabelką liczb, stawiajacą ludziom warunki zbyt wymagające, nie do pogodzenia się, może nawet uwłaczające, np. wolności człowieka, który - według modnych dziś filozofii - powinien czuć się absolutnie wolny w określaniu siebie i świata, w wybieraniu swojej tożsamości indywidualnej czy społecznej, nie licząc się z ograniczeniami nie tylko jakiegoś absolutu, ale choćby prostych liczb, opisujących np. chromosomy czy ,skład” rodziny. Tymczasem właśnie dzięki liczbom, którym posłuszne jest światło - bardzo maleńki fragment widma elektromagnetycznego - możliwy jest prawdziwy postęp technologiczny. Choć to nie jest dla wszystkich wyraźnie widoczne, to właśnie dzięki poważnemu traktowaniu liczb z omawianej Tabeli instytucje nieigrajace z prawdac potrafiac konstruować np. bardzo precyzyjne urządzenia zdolne odbierać niezwykle słabe sygnały z Kosmosu. Takie osiągnięcia na zawsze pozostaną niedostępne dla tych, którzy - jak w skorumpowanej gospodarce - nie liczą się z bilansem liczb.

Co więcej, właśnie dzięki wewnętrznej ascezie liczb z Tabeli 2.1 możliwe jest wszystko to, co rzetelny filozof określa jako „widzenie” czy - gdy go brak - ,ślepota”. Łatwo to pokazać przez kontrast. Gdyby jakiś parlament, na skutek szczególnie pojętej demokracji, chciał ustawowo przesunąć obszar widzialny w tej tabelce np. na obszar promieni $\gamma$ jądrowych $\left(10^{21} \mathrm{~Hz}\right)$, a specjalna firma wyposażałaby obywateli w stosowne naświetlacze, realizujace ten „postęp widzenia”, wszyscy obywatele korzystajaccy z owego „postępu” ulegliby oślepieniu w sposób nieodwracalny. Albo gdyby ,postępowa medycyna", czerpiąc niemałe zyski, sprzedawała w aptekach „nowoczesne ochraniacze” chroniace ludzi przed światłem widzialnym, szybko zamarłoby życie „postępowych” pacjentów. Prawda liczb potrafi być bezwzględna wobec tych, którzy nie traktują jej poważnie. 


\section{Tajemnica liczbowej tabeli}

Słupek liczb omawiany wyżej (Tabela 2.1), którego odkrycie ludzkość może uważać za wielki skok cywilizacyjny, tylko bardzo uważnemu czytelnikowi tej niewielkiej tabelki ukazuje wystarczająco jasno, że sterowanie Kosmosem jest matematycznej natury, jakże innej od ludzkich dekretów. Dla mniej uważnych czytelników tabelka ta jest jedynie zbiorem wyników pomiarów, z którymi trzeba się może liczyć, ale nic ponadto. Trudno się temu nawet dziwić, gdyż przez długi okres czasu uważano (z pewnymi wyjątkami), że matematyka jest jedynie liczbową czy punktową abstrakcją z rzeczywistości i nie ma w niej żadnej mocy, która przypominałaby jakieś sterowanie. Ten przybliżony, obiegowy sposób myślenia o matematyce można odnależć u wielu uczonych także i dziś. Jednym $\mathrm{z}$ jego przejawów jest np. instrumentalne traktowanie matematyki (liczb, dowodów, teorii) czy sprowadzanie jej wyłącznie do tego, co ,siedzi” w głowie jakiegoś ekstrawaganckiego matematyka. To jednak nie wszystko, co o świecie mają do powiedzenia liczby. Dla tych, dla których ten prosty słupek jeszcze nie bardzo ukazuje moc (virtus) matematycznego sterowania, może być pomocna inna tabelka Feynmana.

Przykładem bardziej złożonej struktury, o większej mocy matematycznej niż słupek liczb, jest Tabela $9.2^{4}$. Zawiera ona m.in. powiązane ze sobą ilościowo położenia i prędkości planety w jej ruchu wokół słońca, obliczone w sposób przybliżony z równania na siłę grawitacyjną. Niektórzy filozofowie o skłonnościach do forsowania absolutnej wolności człowieka znowu mogą się poczuć nieswojo wobec mocy, która przemawia z tej tabelki; ale - co może wydawać się dziwne - może ona dotknać poczucia wolności niektórych matematyków, którzy, szanując jedynie dyscyplinę swoich symboli, przestali dbać o ich prawdziwy związek z rzeczywistością i - w granicy ludzkiego umysłu - „tworzą" hiper- czy inne pseudoświaty, uważając, że dotychczas odkryte prawa są zmienne, a tyl-

\footnotetext{
${ }^{4}$ Por. R.P. Feynman, R.B. Leighton, M. Sands, dz. cyt., s. 150.
} 
ko ich teorie fundamentalne ${ }^{5}$. Czym jest zatem tajemnicza Tabela 9.2 ?

Modelowanie świata w granicach ludzkiego umysłu, choćby był to umysł matematyczny, jest - oczywiście - w nauce konieczne do stawiania hipotez, ale jest też podwójnie niebezpieczne, gdy przekroczy się właściwą filozoficznie miarę. Z jednej strony, już liczenie np. chromosomów może „obrażać” wolność wyboru operującą w ramach „wyższej filozofii”, dla której, jeśli liczby do niej nie pasują, to trzeba tak sterować nauka, żeby ominąć liczby. Jest tu więc kontrast między mocą (virtus) liczb a fałszywą filozofią, którą zwalczał m.in. Feynman. Z drugiej strony, mówiąc analogicznie, jeżeli jest się związanym, np. przez stałe przyrody, to chce się z tego wyzwolić i próbować te stałe „uzmiennić”. Jest tu więc tworzenie „rzeczywistości wirtualnej”. W obu przypadkach idzie o to, aby wyzwolić się z mocy (virtus) sterowania matematycznego i zarezerwować sterowanie światem wyłącznie dla człowieka. Wypacza się przez to samą matematykę w podobny sposób, jak to ongiś miało miejsce w ukrywaniu niewymierności długości przekątnej kwadratu jednostkowego czy obecnie jest praktykowane $\mathrm{w}$ „uzmiennianiu wartości" w naukach dotyczących życia. Innymi słowy, próbuje się (w modelowaniu w granicach ludzkiego umysłu) sprawić wrażenie, że tabelki typu Tabeli 9.2 są przypadkowe, że nic nimi nie steruje, że mimo wymowy liczb, nie są one „matematyczne” w głębszym, transcendentnym sensie.

Tymczasem ta skromna i krótka Tabela 9.2 opisuje wektorowe związki położenia i prędkości, którymi rządzi ściśle określona, jedna formuła matematyczna; formuła, której się nie deklaruje (jak dowolny aksjomat), ale którą się odkrywa. Tabela ta nie jest produktem sterowania jakiegoś matematycznie nastawionego ministerstwa, które arbitralnie ustalałoby wzory na powagę nauko-

5 Można tu mówić o teoriach typu wielo-światów czy teorii strun. Być może kiedyś coś z nich stanie się realną nauką, jednak dziś w niektórych środowiskach są one traktowane nazbyt poważnie. Ludzką matematykę też można wykorzystać do tworzenia złudzeń, co od dawna czynią różnej maści magicy. 
wą. Jest ona niematerialnym sygnałem, małym świadectwem porządku, jaki panuje w samej matematyce Kosmosu - świadectwem hierarchicznej relacji, powiązań między światem liczb i światem równań różniczkowych, a nawet więcej - sterującą komunikacją działająca jak język poleceń - jednego, bardzo wyróżnionego równania, z ogromnym zestawem liczb, którym odpowiada coś tak rzeczywistego, jak położenie czy prędkość.

Tabela 9.2 ukazuje tylko to, czy może aż tak wiele, w jaki sposób to jedno, bardzo proste równanie matematyczne steruje ciągami liczb określających wektorowe położenia i prędkości. Matematyka steruje matematyką, określając obiektywną relację ciał fizycznych względem siebie. Od tego sterowania dla położenia i prędkości nie ma ucieczki w irracjonalny ,chaos". Sterowanie to jest ideowo bardzo proste, co wyraża się np. tym, że arytmetyka, używana do kolejnych kroków przybliżonych obliczeń, jest na poziomie niższym niż licealny, niemniej już ona ukazuje, jak język poleceń równania siły grawitacyjnej steruje ruchem planet, ,zarządzając" na dodatek fizyczne prawa, np. Keplerowskie prawa o elipsie czy stałej prędkości polowej. Można stąd wnioskować, że prawa fizyczne pochodzą od mocy (virtus) matematycznej.

Bardziej ogólne tabelki typu Tabeli 9.2 szybko opanowali matematycy i przedstawili swoje analityczne rozwiązanie zagadnienia ruchu dwóch ciał w polu centralnym na wiele ciekawych sposobów. Z tymi bardzo istotnymi skądinąd osiągnięciami wiązała się nieoczekiwanie ważna lekcja pokory. Okazało się, że dla trzech ciał, aby rozwiązanie mogło być dokładnie obliczone, trzeba przyjąć znaczne uproszczenia, zaś w ogólnym przypadku, np. Układu Słonecznego, rozwiązanie analityczne „z góry" jest nieosiągalne; nie poddaje się ono „mocy” ludzkiej matematyki „dokładnej”. Wszystko co można w takich przypadkach, to napisać równanie łączne dla zespołu ciał Układu i dla zadanych, konkretnych warunków początkowych w przybliżonych obliczeniach patrzeć, jak rośnie analogiczna, choć bardziej rozbudowana na wiele ciał, tabelka zawierająca położenia i prędkości planet, którymi steruje to jedno równanie. 
Okaże się przy tej obserwacji niewątpliwie to, że Kepler miał tylko częściowo rację, np. że ruch Księżyca nie jest eliptyczny, bo zniekształca go najmocniej pobliska mu Ziemia itd. Widać tu od innej strony moc (virtus) matematyczną sterowania prawami fizycznymi.

Matematyka sterująca ruchami planet Układu wniosła więc jeszcze coś więcej do kultury - ludzie uświadomili sobie, na jak niskim poziomie jest ich opanowanie choćby czegoś tak prostego, jak opis ciał niebieskich. Oprócz tej ważnej konkluzji ograniczającej, było w tym zawarte również przesłanie głębsze. Ludzie uświadomili sobie wyraźniej, że poznając prawdę - już na tak niskim poziomie - uczestniczą, choć jeszcze bardzo niedojrzale, w jej głębokiej, matematycznej harmonii, a dzięki przybliżonym tabelkom typu 9.2 mogą poprawnie coś sami, lokalnie, własną „mocą” obliczyć, i to coś, co istnieje realnie. Po rachunkach można skierować teleskop w niebo i skonfrontować, być może za jakiś czas, wyniki obliczeń z rzeczywistymi obserwacjami.

Dziś dobrze wiadomo, że Newtonowska grawitacja sama w sobie jest jedynie przybliżeniem. Niemniej jednak już na jej bazie odsłania się bardzo wyraźnie ogólny program fizyki: wyrazić wszystko $\mathrm{w}$ jednym równaniu. Innymi słowy chodzi o to, aby moc (virtus) sterowania obserwablami, pochodząca od jakiegoś jednego równania matematycznego, odkryła dostępny nam rąbek tajemnicy świata. Moc ta nie pochodzi, jak się rzekło, od uczonych, lecz jest odkrywana, odgadywana, odcyfrowywana, obliczana z bardzo grubym przybliżeniem. Z nią się nie dyskutuje i prawdziwi, uczciwi uczeni dobrze o tym wiedzą. Czy jednak wszyscy przyznają się do tego, jak znikoma jest ich własna moc obliczeniowa czy raczej tworzą „,rzeczywistość wirtualną”? Odpowiedż jest, oczywiście, tylko w części pozytywna. Na pocieszenie trzeba jeszcze dopowiedzieć to, że choć ludzka, matematyczna wiedza o Kosmosie jest szczątkowa i gromadzona z ,grubym przybliżeniem”, jest ona jednak realna i otwarta na ciągłe, choć niełatwe, zgłębianie, które może, choćby 
szczątkowo, przetrwać pokolenia ignorujące matematykę lub wciągające ją w sferę iluzji, jak to było wspomiane we Wprowadzeniu.

Skąd mogą pochodzić owe niebezpieczeństwa braku spójności między światem a ludzką kulturą? Otóż modelowanie matematyczne, przez to, że jest bardzo skuteczne w świecie i że jest wiele równań - kandydatów „wyższej matematyki” do sterowania niższą, może prowadzić do swoistej pychy, do „rzeczywistości wirtualnej” mającej sprawić wrażenie, że „wyższa matematyka” jest dowolna, że np. lokalnie siła grawitacji jest odwrotnie proporcjonalna do potęgi wyrażonej nie ,2", ale „1.99”, ,2.01” itp. Tymczasem czym innym jest świadome przybliżenie - zdawanie sobie sprawy z cząstkowego ujęcia świata, a czym innym świadome stwarzanie pozorów, choćby nawet matematycznego ,sterowania”, przejawiające się np. tym, że uważa się, iż sformułowano równania ostateczne rządzące światem w ramach ludzkiej „mocy” obliczeniowej.

W odkryciu grawitacyjnej, fizycznej ,,jedyności” (równania z ,2" - kwadratem odległości) jest jakaś tajemnica, która manifestuje się w tym, że grawitacja wybiera tylko to jedno, sterujące równanie z morza innych możliwości. Fizyka ukazuje więc, że matematyka łączy się wewnętrznie w struktury hierarchicznie sterujące sobą nawzajem i połączone z Kosmosem w sposób niezmiernie selektywny. W kontaktach zaś z uczonymi nierzadko trudno odróżnić, czy to, co mówią jest rzeczywiste czy nie i tu osąd wydać może jedynie filozofia zsynchronizowana z realną prawdą rzeczy. Prawdy, także tej naukowej, szuka się zwykle wśród fikcji, jak w życiu potocznym - mądrości pośród plew. Zaś Ludzkich uzurpatorów sterowania Kosmosem, kosmiczna matematyka nie bierze pod uwagę.

Dlatego obchodzenie się z matematyką wymaga etycznego kryterium rozeznania. Nie chodzi tu o jakiś ,kodeks etyczny”, tworzony ad hoc przez jakieś agencje filozoficzne, ale o coś, co najogólniej można by określić jako poszanowanie realizmu życia, co było ongiś programem filozofii-mądrości, zanim filozofia stała się przedmiotem szkolnym podchodzącym do problemów na zasadzie matematycznych słupków, o których była mowa we Wprowadze- 
niu. Filozofia już od dawna przeżywa swój poważny kryzys: zapomnienia o mądrości, poszukiwania prawdy, uczenia, jak dobrze żyć. Feynmanowska krytyka filozofii nie była więc taka bezpodstawna. Jak zatem szukać etycznego kryterium zastosowań matematyki uprawianej przez ludzi? Ludzkość może dokonać złych wyborów matematycznie wspieranych wbrew matematyczności świata; może zniszczyć sama siebie przez irracjonalność, ale też przez naukowość niszczącą życie. Fizyka matematyczna zakłada prosty program filozoficzny: szukać jednego równania, pośród matematycznego spektrum kandydatów, które steruje wszystkimi innymi zależnościami matematycznymi w Kosmosie. Budzi to nadzieję także dla filozofii, że istnieją poważne racje pośród ograniczonego racjonalnie zgiełku, ukazujące, że warto dobrze żyć w mądrości, ceniąc każde życie. Mimo swej szczątkowej racjonalności, człowiek może etycznie tak dostroić siebie do mocy (virtus) matematycznej sterujacej Kosmosem, by żyć z nią w symbiozie: respektując prawa natury i wyrażając w niej swoją kulturę, afirmujac życie. Prawdziwy filozof to ktoś, kto żyje dobrze pod każdym względem. Można być uczonym i filozofem.

\section{Abstract}

\section{The Might of the Mathematical Control}

One can speak about mathematics too simplistically. On the one hand, school programs are such examples. On the other hand, the function of mathematics in elementary physics very much indicates the profound philosophical significance of mathematics: the author claims that mathematical language is a kind of command language, i.e. it is not just a description, but a control which has a specific power (lat. virtus) to manage the reality. This language has its proper hierarchy and structures which humans only are just starting to understand and to use in basic ways, not without errors. Therefore some ethics regarding human mathematical thinking are needed: the affirmation of life.

Keywords: matehamtics, mathematical language, reality, significance of mathematics 